\title{
Ethnomedicinal Plants from Iraq as Therapeutic Agents against Mycobacterium tuberculosis: A Review
}

\author{
Ali Sami Dheyab ${ }^{1 *}$, Ekremah Kheun Shaker ${ }^{2}$ and Abdul jabbar Khaleel Ibrahim² \\ ${ }^{1}$ Department of Medical Laboratory Techniques, Al Maarif University College, Alanbar, Iraq. ${ }^{2}$ Department of Medical \\ Laboratory Techniques, Al-Rasheed University College, Baghdad, Iraq.
}

\begin{abstract}
Mycobacterium tuberculosis is a highly infectious pathogen, which can affect both humans and animals. The metabolic products of this bacterium affect the pulmonary, nervous, lymphatic, and cardiovascular systems. The aim of this review is to provide information on certain local herbs from Iraq, which have been found to be effective against Mycobacterium tuberculosis. In this report, we have reviewed 13 medicinal plants and their anti-mycobacterial activities. The family, traditional medicinal uses, common local names, in vitro activity of the crude extract, and information about bioactive chemical composition of these plant species have been described. The crude extracts of these medicinal plants can be used to develop novel drugs against tuberculosis.
\end{abstract}

Keywords: Medicinal plants; Mycobacterium tuberculosis; Anti-mycobacterial activity; Iraq.

*Correspondence: alisamimicrobiology@gmail.com

(Received: 11 June 2019; accepted: 13 August 2019)

Citation: Ali Sami Dheyab, Ekremah Kheun Shaker and Abdul jabbar Khaleel Ibrahim, Ethnomedicinal Plants from Iraq as Therapeutic Agents against Mycobacterium tuberculosis: A Review, J Pure Appl Microbiol., 2019; 13(3): 1419-1427. https://doi. org/10.22207/JPAM.13.3.12

(C) The Author(s) 2019. Open Access. This article is distributed under the terms of the Creative Commons Attribution 4.0 International License which permits unrestricted use, sharing, distribution, and reproduction in any medium, provided you give appropriate credit to the original author(s) and the source, provide a link to the Creative Commons license, and indicate if changes were made. 


\section{INTRODUCTION}

Mycobacterium tuberculosis is an acid-fast, Gram-positive bacterium that does not form spores; it causes a zoonotic disease known as tuberculosis (TB) in both humans and animals ${ }^{1}$. The disease attacks several organs in the body such as the lungs, skeletal system, brain, lymphatic system, and cardiovascular system. The severity of this disease depends on certain factors, which include the genetic characteristics of the host, environmental factors, and genetic polymorphisms ${ }^{2}$. Iraq is one of the countries with high incidence of TB among the countries in the Eastern Mediterranean Region ${ }^{3}$. A WHO report estimated an incidence rate of approximately 20,000 TB patients with a combined mortality of more than 4000 each year. Moreover, the estimated number of multiple drug resistance-tuberculosis (MDR-TB) cases is approximately $6.1 \%$ of all the newly reported TB cases ${ }^{4}$. A previous study showed the prevalence of TB in Baghdad between 2012 and 2016 and concluded that these cases occur more frequently in women than in men ${ }^{3}$. This may be due to lack of safety, low individual economic status, irregular treatment courses, and also because many cases go unreported. The incidence of the disease can be improved by detecting the disease early, implementing adequate therapy, as well as educating the people about the modes of disease transmission ${ }^{5-7}$.

Irrespective of whether the TB is latent or active, antibiotics are generally used for treating the infected patients. The drugs used against TB include first, second and third-line common antibiotics such as isoniazid, rifampin, pyrazinamide, ethambutol, streptomycin, amikacin, kanamycin, capreomycin, quinolone, and ethionamide ${ }^{8}$. However, these antibiotics have severe side-effects and Mycobacterium tuberculosis can easily develop resistance towards these drugs. In addition, the condition of most patients starts declining within a year of treatment due to non-compliance with the medication course, resulting in a more severe, antibioticresistant condition ${ }^{9-11}$. Due to the resistance mechanism of Mycobacterium tuberculosis, it sometimes occurs along with HIV infection, and hence, there is an urgent need to develop novel therapeutic agents. Active compounds isolated from herbal sources can be effective and might be used as substitutes for the antibiotics used against $\mathrm{TB}^{12-14}$.

\section{METHODOLOGY}

The information in this article takes the reader through the following keywords: "extract", "medicinal plants" and "anti-mycobacterial". We searched for these keywords using electronic databases including Science Direct, Google scholar, PubMed and Scopus. We included both in vivo and in vitro studies in our review.

\section{Ethno-therapy for treatment of tuberculosis} caused by Mycobacterium tuberculosis

We selected 13 plants, which have been known to have potential inhibitory effects on Mycobacterium tuberculosis, in this study. Between the years 2000 and 2018, the reports published in Iraq included the following medicinal plants: Apium graveolens, Arachis hypogaea, Arganiaspinosa L, Camphor, Cinnamomum cassia, Commiphora molmol, Cuminum cyminum, Lepidium sativum, Linum usitatissumun, Nigella sativa, Pimpinella anisum, Piper nigerum, and Trigonella foenumgraecum.

\section{Apium graveolens}

In Iraq, this plant is known as Karafs and its common English name is Celery. It is commonly cultivated in the European region as a food crop and it is also grown in Algeria, Egypt and the central region of Kingdom of Saudi Arabia (KSA) ${ }^{15}$. The seeds of Apium graveolens have been largely used in local and traditional medicine to treat hepatic disorders, jaundice, arthritis, high uric acids levels and many inflammatory diseases ${ }^{16-18}$. Previous ethnomedicinal studies have shown that celery alleviates digestible disturbances, central nervous system and cardiovascular disorders, and also has antimicrobial, anti-inflammatory, and several other pharmacological effects ${ }^{19-21}$. This study reviewed the effects of this plant on Mycobacterium tuberculosis using $200 \mathrm{mg} / \mathrm{ml}$ of whole-plant extract made using $70 \%$ ethanol and found that it inhibited the growth of MTB (only 20 colonies appeared after an incubation period of 4 weeks) ${ }^{22}$.

\section{Arachis hypogaea}

This plant species is a member of the Fabaceae family, which is known as Fustik Abeed and Fustic wdani in Arabic and its common English names are groundnut/peanut. It is mainly grown 
in tropical countries and also cultivated in some sub-tropical areas in different parts of the world ${ }^{23}$. The parts of this plant have several traditional medicinal uses such as the use of peanut oil to treat crust formation in certain skin diseases, for neonatal care, to relieve itching of dermal areas in cases of eczema and dry skin ${ }^{24}$. Modern research on the peanut plant extract has shown its antioxidant properties and in-vitro studies have shown that it possesses free radical scavenging, antimicrobial, anti-parasitic and anti-inflammatory properties ${ }^{25-27}$. Further clinical research has shown that peanut skin has an anti-allergic effect as it contains large amounts of polyphenols ${ }^{28,29}$. The application of $70 \%$ ethanol extract of this plant on Mycobacterium tuberculosis (MTB) at $200 \mathrm{mg} / \mathrm{ml}$ concentration showed no growth of MTB ${ }^{22}$.

\section{Arganiaspinosa $L$.}

This plant is a small tree from the Amaranthaceae family. It grows in North African regions, especially in Morocco, and the oilproducing varieties of this plant can also be grown in jungles. In its native country, this plant is traditionally used for nutritive as well as several other purposes ${ }^{30}$. On the other hand, modern uses of argan oil, produced by this plant, have shown anti-bacterial activity on diseases involving Staphylococcus aureus (MRSA) and Pseudomonas aeruginosa infection $\mathrm{s}^{31,32}$. In addition, several papers have mentioned the activity of argan oil in different diseases such as cancer, heart disease, diabetes and thyroid hormone disturbances ${ }^{33}$ The current review aims to elucidate the effects of argan oil against Mycobacterium tuberculosis. Its therapeutic effects depend on its rich chemical composition including oleic, linoleic, palmitic, stearic and linolenic acids and mixtures of these chemicals at concentrations of 2.5:7.5 and 3:7 yielded good inhibitory effect on Mycobacterium tuberculosis ${ }^{30}$.

\section{Camphor}

This chemical is from a plant belonging to the Lauraceae family and it is derived from the camphor wood laurel tree. It is white in color, crystalline in texture, has a specific odor and intense taste ${ }^{34}$. The tree is natively cultivated in India, Mongolia, Japan, Taiwan, and also in the Southern region of USA ${ }^{35}$. The essential oil from this plant has been traditionally used to soothe muscle pain, joint conditions, dermatological conditions, cold, and bronchial congestion ${ }^{36}$. Latest studies have shown its pharmaceutical applications as an analgesic, antipyretic, antiinflammatory, anti-spasmodic, mild expectorant and for alleviating nasal disorders ${ }^{35,37}$. The volatile oil, which has major medicinal properties, contains safrole, linalool, eugenol, and terpineol and the leaf of the plant is also a powerful source of linalool $(94.9 \%)^{38}$. The camphor plant extract showed clear activity at $200 \mathrm{mg} / \mathrm{ml}$ concentration against MTB with only 18 colonies appearing after an incubation period of 4 weeks ${ }^{22}$.

\section{Cinnamomum cassia}

This plant is classified under the Lauraceae family. It is commonly known as Chinese cassia, and it is cultured in various regions in the world. It is harvested from the inner cortex of the tree belonging to the genus Cinnamomum ${ }^{39}$. The cinnamomum plant has been used for the oldest traditional herbal medicine used and it is also used in mouth fresheners and chewing gums for its flavor ${ }^{40,41}$. In addition, the cinnamon plant improves digestive ability and reduces colon disorder ${ }^{42,}{ }^{43}$. All parts of the cinnamon tree, including the leaves, bark, root, or fruits, possess medicinal properties. The bark and leaves contain the volatile oils in large amounts with chemicals having medicinal and pharmaceutical properties such as antimicrobial, antioxidant and anti-inflammatory activities ${ }^{41,44}$. Latest studies elucidating the local uses of Cinnamomum plants have shown that they have anti-tuberculosis activity $^{45}$.

\section{Commiphora molmol}

This plant is classified under the Burseraceae family and its common name myrrh is derived from the Arabic word Mur. Various species of the Commiphora plant are cultivated in different regions of the world ${ }^{46}$. The traditional medicinal use of this genus Commiphora includes treatment of headache, wound care, joint pain, bone fractures, and diarrhea ${ }^{47}$. Latest research shows that the active compound of commiphora extract has anti-cancer activity and in vitro experiments have shown its anti-microbial activity ${ }^{48,49}$. Latest studies on the application of Commiphora molmol in treating tuberculosis have shown its activity against clinical isolated TB sample at $200 \mathrm{mg} / \mathrm{ml}$ concentration, resulting in no growth of $\mathrm{MTB}^{22}$. 


\section{Cuminum cyminum}

This plant species is a member of the Apiaceae family, which is known as Kamoun in Arabic and as Cumin in English ${ }^{50}$. It is cultivated and grown in the MENA regions - Middle East and North Africa. In addition, the plant is also grown in the United States of America, India and China ${ }^{50,51}$. The traditional medicinal uses of cumin include as a treatment for diarrhea and jaundice, and it also has diuretic and astringent properties. The oil of the cumin plant is used in food manufacturing for making cheese and soups ${ }^{52}$. The extract of the cumin seed has anti-microbial and bactericidal properties, as shown by in vitro experiments ${ }^{53}$. Through phytochemical analysis of the parts of this plant, the phenolic content in the methanol extract was evaluated and found to exhibit anti-oxidant and anti-inflammatory activities ${ }^{54,55}$. The crude plant extract made using $70 \%$ ethanol at $200 \mathrm{mg} /$ $\mathrm{ml}$ concentration completely inhibited the growth of MTB after an incubation period of 4 weeks ${ }^{22}$.

\section{Lepidium sativum}

This species of herbs is a common garden plant. It is classified under the Brassicaceae family and is found in countries like Africa and Ethiopia. However, it can also be found in different parts of the world such as Southwest Asia ${ }^{56}$. The plant has several names including garden pepper cress, pepperwort and El Rashad ${ }^{57}$. It is used in the Arabic countries as traditional medicine to treat asthma, cough, bronchitis and as an expectorant ${ }^{57,58}$. The chemicals found in this plant, such as oleic acid, stearic acid, linoleic acid and ascorbic acid, have several pharmaceutical effects. All of the chemicals have significant diuretic, anti-inflammatory, antidiarrheal, anti-microbial, analgesic and laxative activities ${ }^{59-61}$. Through whole plant extraction using $70 \%$ ethanol solvent, its activity against MTB was shown; at $200 \mathrm{mg} / \mathrm{ml}$ concentration, it completely suppressed MTB growth (no colonies seen).

\section{Linum usitatissumun}

This particular plant species has been cultivated for its oil since a long time. Its common name is flax or linseed and it belongs to the Linaceae family ${ }^{62}$. The flax plant is native to Egypt and it is commonly distributed between the Arabic gulf and Red Sea. However, it can also be found in certain other countries like India, Pakistan, and Afghanistan ${ }^{63}$. There are quite a few traditional medicinal uses of Linum usitatissimum and it has several therapeutic benefits such as an anti-tussive, laxative, expectorant, and diuretic ${ }^{64}$. The linseed shell is characterized by its shape, which is hard with different colors. Its chemical composition is as follows: $41 \%$ fat, $28 \%$ fiber, and $20 \%$ protein with high internal polyunsaturated fatty acids content ${ }^{65}$. In modern therapy, there are abundant data available on the properties of flaxseed such as its anti-coagulant, anti-diabetic, anti-microbial, anti-oxidative activities as well as its nephro-, hepato- and cardio-protective effects ${ }^{66-68}$. The ethanol extract of flax plant showed antituberculosis activity at $200 \mathrm{mg} / \mathrm{ml}$ concentration and only 25 MTB colonies grew after the 4-week incubation period $^{22}$.

\section{Nigella sativa}

This plant is commonly known as black seed in Arabic and its common English name is black cumin ${ }^{69}$. It is a herb belonging to the Ranunculaceae family ${ }^{70}$. Nigella seeds have been used to improve human health, particularly in the Middle Eastern countries. This plant species is cultivated in many areas in the world, especially in Arabic countries. It has been, in fact, mentioned by Prophet Mohammed as having the property to enhance physical power and health ${ }^{71,72}$. Nigella sativa is commonly used in traditional medicine as a diuretic, and as a cure for liver disorders, digestive system problems, fever, and jaundice ${ }^{72,73}$. Different studies describing the modern applications of the black nigella seeds have shown that it has therapeutic activity against several conditions such as bacterial, fungal, parasitic, and viral infections as well as in metabolic disorders, hypertension, diabetes, gastrointestinal disease and hepatic disorders ${ }^{69,72}$. The published articles on the black seed plant show chemical composition consisting of high oil content of approximately 28 to $36 \%$ as well as different bio-active chemicals such as flavonoids and saponins. The pharmaceutical benefits exerted by these phytochemicals include anti-cancer, anti-microbial, anti-inflammatory, anti-oxidant and detoxifying activities ${ }^{73}, 74$. This plant is also effective against Mycobacterium tuberculosis and it showed significant inhibitory effect at a concentration ratio of 2.5:7.5 and 3:7 after completion of the incubation period ${ }^{75}$.

\section{Pimpinella anisum}

Pimpinella anisum is one of the oldest herbal medicinal plants that belongs to the 
Umbelliferae family. It is grass-like in shape and is about $50 \mathrm{~cm}$ in length. Its common English name is anise ${ }^{76}$. Pimpinella anisum is grown and cultivated in various areas such as Asia, Middle Eastern regions like Iran and Egypt. It has also been reported to grow in Europe and Mexico ${ }^{77}$. Every year, the anise fruit is harvested between August and September. Its traditional medicinal uses include alleviation of various conditions such as digestive disorders, GIT spasms, and constipation and also to increase the breast milk production in women $^{76,77}$. The secondary metabolism products of this plant consist of various chemicals with anti-microbial and anti-oxidant activities [78-80]. Several studies in the medical field have shown that the essential oils of this plant have many positive health benefits such as anti-inflammatory, analgesic, anti-convulsant and hepatoprotective activities ${ }^{81-83}$. The $70 \%$ ethanol whole-plant extract along with distilled water showed significant inhibitory activity at $200 \mathrm{mg} / \mathrm{ml}$ concentration against MTB growth in the 4-week incubation period as only 3 colonies were seen ${ }^{22}$.

\section{Piper nigerum}

Piper nigerum is commonly known as black pepper and it is considered to be the oldest medicinal herb in the world. It is grown in different regions like Asia, Europe and Africa ${ }^{84}$. In Arabic, it is known as Filfil Aswad and it belongs to the Piperaceae family ${ }^{85}$. It has several important uses in traditional medicine and has been used to treat preclinical cases such as asthma, skin disorder, sore throat, snake bite and as an antipyretic medication ${ }^{86}$. The black pepper seed contains several potent chemicals. Many studies have shown that it has anti-bacterial, anti-diarrheal, anti-colic, anti-fungal and anti-inflammatory activity against various infectious disease ${ }^{87,88}$. In this review, we have shown the anti-mycobacterial activity of Piper nigerum, which has potent inhibitory activity at $200 \mathrm{mg} / \mathrm{ml}$ concentration and suppresses the growth of MTB with only 4 colonies seen after the 4-week incubation period ${ }^{22}$.

\section{Trigonella foenum-graecum}

This medicinal plant, commonly known as fenugreek, is considered to be one of the oldest plants used in traditional medicine. It belongs to the Papilionaceae family ${ }^{89}$. It is cultivated throughout the world due to its adaptive behavior ${ }^{90}$. Although it is grown worldwide under various climatic conditions, it is especially found in Asia and Africa. Due to its widespread distribution, its medicinal role has been well documented. For instance, in Iran, the extract of this plant is used to lower blood sugar leve ${ }^{91}$. In China, its seeds are used to treat digestive disorders, gastritis, and gastric ulcers and also, in food manufacturing ${ }^{90}$. Several studies have reported the bioactive chemicals found in this plant and have shown their applications in the medical field. Furthermore, it has many pharmacological activities such as hypoglycemic, anti-diabetic, anti-lipidemic, anticancer, antimicrobial and anti-inflammatory activities ${ }^{92,93}$. The plant has clear anti-mycobacterial effect as after completion of the entire incubation of 4 weeks, no MTB growth was seen when it was used at 200 $\mathrm{mg} / \mathrm{ml}$ concentration ${ }^{22}$.

\section{CONCLUSION}

It is evident that the aforementioned herbal medicinal plants from Iraq exhibit antimycobacterial activity and hence, can be used against Mycobacterium tuberculosis. There is a significant positive correlation between the traditional used of medicinal plants and their anti-mycobacterial activity. Further research in the field of modern pharmaceutical science should be conducted to isolate and identify the bioactive chemical compounds from these plants. We expect that these findings will encourage the researchers to engage in drug discovery and develop novel natural products that may eventually facilitate the development of a novel anti-TB drug.

\section{ACKNOWLEDGEMENTS}

We are thankful to Al Maarif University College (AUC) Alanbar, Iraq and the Dean of the college for providing and supporting the study.

\section{CONFLICT OF INTEREST}

The authors declare that there is no conflict of interest.

\section{FUNDING}

None.

\section{DATA AVAILABILITY}

All datasets generated or analysed during this study are included in the manuscript. 


\section{AUTHORS' CONTRIBUTION}

All authors have made substantial, direct and intellectual contribution to the work and approved it for publication.

\section{ETHICS STATEMENT}

This research article does not contain any studies involved with human participants or animals.

\section{REFRENCES}

1. Cavalli, Z., et al., Clinical presentation, diagnosis, and bacterial epidemiology of peritoneal tuberculosis in two university hospitals in France. Infectious diseases and therapy, 2016. 5(2): p. 193-199. https://doi. org/10.1007/s40121-016-0113-2

2. Bakayoko, A., et al., Tuberculose multir'sistante chez le personnel de sant' en Cote d'Ivoire. Revue de Pneumologie Clinique, 2016. 72(2): p. 142-146. https:// doi.org/10.1016/j.pneumo.2015.09.006

3. Ali Kareem Durib, M., Prevalence of Tuberculosis in Baghdad, Iraq 2012-2016. International Journal of Scientific and Research Publications, 2018. 8(2): p. 565-570.

4. Organization, W.H., Global tuberculosis report 2018. 2018: World Health Organization.

5. Merza, M.A., et al., First insight into the drug resistance pattern of Mycobacterium tuberculosis in Dohuk, Iraq: using spoligotyping and MIRU-VNTR to characterize multidrug resistant strains. Journal of infection and public health, 2011. 4(1): p. 41-47. https://doi. org/10.1016/j.jiph.2010.11.002

6. Merza, M.A. and A.M. Salih, First insight into the genetic diversity of Mycobacterium tuberculosis strains from patients in Duhok, Iraq. International journal of mycobacteriology, 2012. 1(1): p. 13-20. https://doi.org/10.1016/j.ijmyco.2012.01.003

7. Ahmed, M.M., A.A. Velayati, and S.H. Mohammed, Epidemiology of multidrug-resistant, extensively drug resistant, and totally drug resistant tuberculosis in Middle East countries. International journal of mycobacteriology, 2016. 5(3): p. 249-256. https://doi. org/10.1016/j.ijmyco.2016.08.008

8. Chetty, S., et al., Recent advancements in the development of anti-tuberculosis drugs. Bioorganic \& medicinal chemistry letters, 2017. 27(3): p. 370-386. https://doi.org/10.1016/j.bmcl.2016.11.084

9. Adaikkappan, P., M. Kannapiran, and A. Anthonisamy, Antimycobacterial activity of Withania somnifera and Pueraria tuberosa against Mycobacterium tuberculosis H37Rv. J. Acad. Indus. Res, 2012. 1(4): p. 153-156.

10. Hoagland, D.T., et al., New agents for the treatment of drug-resistant Mycobacterium tuberculosis. Advanced drug delivery reviews, 2016. 102: p. 55-72. https://doi. org/10.1016/j.bmcl.2016.11.084

11. Islam, M.M., et al., Drug resistance mechanisms and novel drug targets for tuberculosis therapy. Journal of genetics and genomics, 2017. 44(1): p. 21-37. https:// doi.org/10.1016/j.jgg.2016.10.002
12. Ganihigama, D.U., et al., Antimycobacterial activity of natural products and synthetic agents: Pyrrolodiquinolines and vermelhotin as anti-tubercular leads against clinical multidrug resistant isolates of Mycobacterium tuberculosis. European journal of medicinal chemistry, 2015. 89: p. 1-12. https://doi. org/10.1016/j.ejmech.2014.10.026

13. Kaur, R. and H. Kaur, Antitubercular activity and phytochemical screening of selected medicinal plants. Orient J Chem, 2015. 31(1): p. 597-600. https://doi. org/10.13005/ojc/310176

14. Makgatho, M., W. Nxumalo, and L. Raphoko, Anti-mycobacterial,-oxidative,-proliferative andinflammatory activities of dichloromethane leaf extracts of Gymnosporia senegalensis (Lam.) Loes. South African Journal of Botany, 2018. 114: p. 217-222. https://doi.org/10.1016/j.sajb.2017.11.002

15. Al-Asmari, A.K., et al., A review of hepatoprotective plants used in Saudi traditional medicine. EvidenceBased Complementary and Alternative Medicine, 2014. 2014. https://doi.org/10.1155/2014/890842

16. Kooti, W., et al., A review on medicinal plant of Apium graveolens. Advanced Herbal Medicine, 2015. 1(1): p. 48-59.

17. Asif, H., et al., Monograph of Apium graveolens Linn. Journal of Medicinal Plants Research, 2011. 5(8): p. 1494-1496.

18. Ahmed, Q. and K. Sayedda, Effect of celery (Apium graveolens) seeds extract on protease inhibitor (ritonavir) induced dyslipidemia. NJIRM, 2012. 3(1): p. 52-56.

19. Naema, N.F., B. Dawood, and S. Hassan, A study of some Iraqi medicinal plants for their spasmolytic and antibacterial activities. J Basrah Res, 2010. 36(6): p. 67-73.

20. Brankovic, S., D. Kitic, and M. Radenkovic, Hypotensive and cardioinhibotory effects of the aqueous and ethanol extracts of Celery (Apium graveolens, Apiaceae). Acta Medica Medianae, 2010. 49(1): p. 13-16.

21. Al-Snafi, A.E., The pharmacology of Apium graveolens.-A review. International Journal for Pharmaceutical Research Scholars, 2014. 3(1-1): p. 671-677.

22. Abbas, M.S., Study the effect of some plants extracts on growth of Mycobacterium tuberculosis in Comparison with Ethambutol. The Iraqi Journal of Veterinary Medicine, 2011. 35(1): p. 129-134.

23. Al-Snafi, A.E., Chemical Constituents and Pharmacological Activities of Arachis hypogaea. A Review. International Journal for Pharmaceutical Research Scholars (IJPRS), 2014. 3(1): p. 615-623.

24. Hassan2, A.H.A.-A.a.Z.H., ANTIBACTERIAL ACTIVITY OF Arachis hypogaea L. SEED COAT EXTRACT CULTIVATED IN IRAQ. Pak. J. Biotechnol., 2017. 14(4): p. 601 - 605

25. Lin Tang2., J.S., Hui Cui Zhang1,2, Chu Shu Zhang1, Li Na Yu1, Jie Bi1, Feng Zhu1, Shao Fang Liu1, Qing Li Yang1*, Evaluation of Physicochemical and Antioxidant Properties of Peanut Protein Hydrolysate. PLos one 2012. 7(5): p. 7.

26. Prabasheela, B., et al., Phytochemical analysis and antioxidant activity of Arachis hypogeal. Journal of Chemical and Pharmaceutical Research, 2015. 7(10): 
p. 116-121.

27. Park, S., et al., Inhibitory Effect of Arachis hypogaea (Peanut) and Its Phenolics against MethylglyoxalDerived Advanced Glycation End Product Toxicity. Nutrients, 2017. 9(11): p. 1214. https://doi. org/10.3390/nu9111214

28. Tomochika, K., et al., Effects of peanut-skin procyanidin A1 on degranulation of RBL-2H3 cells. Bioscience, biotechnology, and biochemistry, 2011. 75(9): p. 16441648. https://doi.org/10.1271/bbb.110085

29. Sim, E.W., S.Y. Lai, and Y.P. Chang, Antioxidant capacity, nutritional and phytochemical content of peanut (Arachis hypogaea L.) shells and roots. African Journal of Biotechnology, 2012. 11(53): p. 11547-11551.

30. Prof. Dr. Habeeb Sahib Naher1*, A.P.A.K.A.-S., Novel Anti- tuberculosis Compound. IOSR Journal of Pharmacy and Biological Sciences (IOSR-JPBS), 2014. 9(5): p. 5.

31. Prof. Dr. Habeeb Sahib Naher1* Lec.Dr Hussein Oleiwi Al-Dahmoshi, A.L.N.S.A.-K., Assist. Prof.Anwar Kadhim Al-Saffar, Anti-Pseudomonal Effect of Argan Oil on Pseudomonas aeruginosa Recovered from Burn Patients in Hilla City, Iraq. International Journal of Research in Science, 2015. 1(2): p. 5. https://doi. org/10.24178/ijrs.2015.1.2.23

32. Dr. Habeeb Saheb Naher, A.K.A.-S., Dr. Hussein Oleiwi Muttaleb Al-Dahmoshi, Noor Salman Al-Khafaji, Noor Saadallah Naji \& Ahmed Abbas Abed Zuwaid, Argan Oil as A Novel Anti-Methicillin Resistance Staphylococcus Aureus (MRSA), Iraq. Global Journal of Medical research: Microbiology and Pathology, 2015. 14(3): p. 4.

33. Hanae El Monfaloutia, b., Dom Guillaumea, $\mathrm{Cl}$ ment Denheza and Zoubida Charroufb, Therapeutic potential of argan oil: a review. journal of pharmacy and pharmacology 2010. 62: p. 7. https://doi. org/10.1111/j.2042-7158.2010.01190.x

34. Hamidpour, R., et al., Camphor (Cinnamomum camphora), a traditional remedy with the history of treating several diseases. Int. J. Case Rep. Images, 2013. 4(2): p. 86-89. https://doi.org/10.5348/ijcri2013-02-267-RA-1

35. Singh, R. and T. Jawaid, Cinnamomum camphora (Kapur). Pharmacognosy Journal, 2012. 4(28): p. 1-5. https://doi.org/10.5530/pj.2012.28.1

36. Jadhav, M., R. Sharma, and G.A. Rathore Mansee, Effect of Cinnamomum camphora on human sperm motility and sperm viability. J Clin Res Lett, 2010. 1(1): p. 01-10.

37. Chelliah, D.A., Biological activity prediction of an ethno medicinal plant Cinnamomum camphora through bioinformatics. Ethnobotanical leaflets, 2008. 2008(1): p. 22.

38. Garg, N. and A. Jain, Therapeutic and Medicinal Uses of Karpura-A Review. International Journal of Science and Research, 2017. 6(4): p. 1174-81.

39. Ranasinghe, P., et al., Medicinal properties of 'true'cinnamon (Cinnamomum zeylanicum): a systematic review. BMC complementary and alternative medicine, 2013. 13(1): p. 275. https://doi. org/10.1186/1472-6882-13-275

40. Jakhetia, V., et al., Cinnamon: a pharmacological review. Journal of advanced scientific research, 2010.
1(2): p. 19-23.

41. Rao, P.V. and S.H. Gan, Cinnamon: a multifaceted medicinal plant. Evidence-Based Complementary and Alternative Medicine, 2014. 2014. https://doi. org/10.1155/2014/642942

42. Wondrak, G., et al., The cinnamon-derived dietary factor cinnamic aldehyde activates the Nrf2-dependent antioxidant response in human epithelial colon cells. Molecules, 2010. 15(5): p. 3338-3355. https://doi. org/10.3390/molecules15053338

43. Gruenwald, J., J. Freder, and N. Armbruester, Cinnamon and health. Critical reviews in food science and nutrition, 2010. 50(9): p. 822-834. https://doi. org/10.1080/10408390902773052

44. Nabavi, S., et al., Antibacterial effects of cinnamon: From farm to food, cosmetic and pharmaceutical industries. Nutrients, 2015. 7(9): p. 7729-7748. https:// doi.org/10.3390/nu7095359

45. Ahmed, H.M., Ethnopharmacobotanical study on the medicinal plants used by herbalists in Sulaymaniyah Province, Kurdistan, Iraq. Journal of ethnobiology and ethnomedicine, 2016. 12(1): p. 8. https://doi. org/10.3390/nu7095359

46. El Ashry, E., et al., Components, therapeutic value and uses of myrrh. Die Pharmazie-An International Journal of Pharmaceutical Sciences, 2003. 58(3): p. 163-168.

47. Hana, D.B., et al., Antibacterial activity of Commiphora molmol extracts on some bacterial species in Iraq. Sch. Acad. J. Pharm., 2016. 5: p. 406-412.

48. Alzahrani, H.A., B.A. Bakhotmah, and L. Boukraa, In Vitro susceptibility of diabetic wound bacteria to mixtures of honey, Commiphora molmol and Nigella sativa. Open Nutraceuticals Journal, 2011. 4: p. 172175. https://doi.org/10.2174/1876396001104010172

49. Abdulkalig Babiker Hassana, S.M.A.S.b., Suhaib Ibrahim Alkhamaisehc, Mohammed Qumani and F.O.A. Ahmedd, Mishary Hamood Al-gholaigahe, Mishaal Mohammad Alqahtanie ,Meshaal Ghzzai Alshammarie, Mohd Adnan Kausarb*, Antibacterial Activity Of Commiphora Molmol In Wound Infections. Biochemical and Cellular Archives, 2017. 17(2): p. 7.

50. Al-Snafi, A.E., The pharmacological activities of Cuminum cyminum-A review. IOSR Journal of Pharmacy, 2016. 6(6): p. 46-65.

51. Dhaliwal, H.K., et al., Phytopharmacological properties of Cuminum cyminum linn. as a potential medicinal seeds: An overview. World Journal of Pharmacy and Pharmaceutical Sciences, 2016. 5(6): p. 478-489.

52. Parthasarathy, V., B. Chempakam, and T. Zachariah, Chemistry of Spices. CAB International, Wallingford. 2008, Oxford-shire, UK. https://doi. org/10.1079/9781845934057.0000

53. Bameri, Z., et al., Antimicrobial activity of Cyminum cuminum against biofilm E. coli. Intern Res J Appl Basic Sci, 2013. 6(3): p. 286-288.

54. Nadeem, M. and A. Riaz, Cumin (Cuminum cyminum) as a potential source of antioxidants. Pak J Food Sci, 2012. 22(2): p. 101-7.

55. Singh, R.P., H. Gangadharappa, and K. Mruthunjaya, Cuminum cyminum-A popular spice: An updated review. Pharmacognosy Journal, 2017. 9(3). https:// doi.org/10.5530/pj.2017.3.51 
56. Falana, H., W. Nofal, and H. Nakhleh, A Review Article Lepidium Sativum (Garden cress). 2014, ResearchGate.

57. Rehman, N.-u., et al., Pharmacological basis for the medicinal use of Lepidium sativum in airways disorders. Evidence-Based Complementary and Alternative Medicine, 2012. 2012. https://doi. org/10.1155/2012/596524

58. Manohar, D., et al., Ethnopharmacology of Lepidium sativum Linn (Brassicaceae): a review. International journal of phytothearpy research, 2012. 2(1): p. 1-7.

59. Doke, S. and M. Guha, Garden cress (Lepidium sativum L.) Seed-An Important Medicinal Source: A. Cellulose, 2014. 9: p. 0.03 .

60. Sharma, S. and N. Agarwal, Nourishing and healing prowess of garden cress (Lepidium sativum Linn.)-A review. 2011.

61. Mehmood, M.H., K.M. Alkharfy, and A.-H. Gilani, Prokinetic and laxative activities of Lepidium sativum seed extract with species and tissue selective gut stimulatory actions. Journal of Ethnopharmacology, 2011. 134(3): p. 878-883. https://doi.org/10.1016/j. jep.2011.01.047

62. Jhala, A.J. and L.M. Hall, Flax (Linum usitatissimum L.): current uses and future applications. Aust. J. Basic Appl. Sci, 2010. 4(9): p. 4304-4312.

63. Amin, T. and M. Thakur, A comparative study on proximate composition, phytochemical screening, antioxidant and antimicrobial activities of Linum usitatisimum L.(flaxseeds). Int. J. Curr. Microbiol. App. Sci, 2014. 3(4): p. 465-481.

64. Umer, K.H., et al., Therapeutics, phytochemistry and pharmacology of Alsi (Linum usitatissimum Linn): An important Unani drug. Journal of Pharmacognosy and Phytochemistry, 2017. 6(5): p. 377-383.

65. Pradhan, R.C., et al., Supercritical $\mathrm{CO} 2$ extraction of fatty oil from flaxseed and comparison with screw press expression and solvent extraction processes. Journal of Food Engineering, 2010. 98(4): p. 393-397. https://doi.org/10.1016/j.jfoodeng.2009.11.021

66. Rashid, N., et al., Alsi (Linum usitatissimum (Linn.): A potential multifaceted Unani drug. Journal of Pharmacognosy and Phytochemistry, 2018. 7(5): p. 3294-3300.

67. Thakur, T.A.a.M., A Comparative Study on Proximate Composition, Phytochemical Screening, Antioxidant and Antimicrobial Activities of Linum usitatisimum $\mathrm{L}$. (flaxseeds). Int.J.Curr.Microbiol.App.Sci, 2014. 3(4): p. 17.

68. Rath B. P., Pradhan D., Antidepressant Activity of Linum usitatissimum Extract. International Journal of Pharmacognostic and Phytochemical Research. 2012; 1(2); 29-32.

69. Gilani, A.-u.H., Q. Jabeen, and M.A.U. Khan, A review of medicinal uses and pharmacological activities of Nigella sativa. Pak J Biol Sci, 2004. 7(4): p. 441-51. https://doi.org/10.3923/pjbs.2004.441.451

70. Ahmad, A., et al., A review on therapeutic potential of Nigella sativa: A miracle herb. Asian Pacific journal of tropical biomedicine, 2013. 3(5): p. 337-352. https:// doi.org/10.1016/S2221-1691(13)60075-1

71. Gali-Muhtasib, H., N. El-Najjar, and R. Schneider-Stock, The medicinal potential of black seed (Nigella sativa) and its components. Advances in Phytomedicine, 2006. 2: p. 133-153. https://doi.org/10.1016/S1572557X(05)02008-8

72. Almatrafi, A.A., Medicinal Uses of Nigella Sativa (Black Seeds). 2016.

73. Rajsekhar, S. and B. Kuldeep, Pharmacognosy and pharmacology of Nigella sativa-A review. Int Res $J$ Pharm, 2011. 2(11): p. 36-9.

74. Zafar, K., et al., Pharmacological activity of Nigella sativa: A review. World J. Pharm. Sci, 2016. 45: p. 234241.

75. AL-Saffar, A. and H. Al-Dahmoshi, Effect of Argan Oil-Hydrogen Peroxide Mixture on Mycobacterium tuberculosis-In Vitro. J Med Microb Diagn S, 2015. 3: p. 2161-0703. https://doi.org/10.4172/2161-0703. S3-008

76. Shojaii, A. and M. Abdollahi Fard, Review of pharmacological properties and chemical constituents of Pimpinella anisum. ISRN pharmaceutics, 2012. 2012. https://doi.org/10.5402/2012/510795

77. Anwar, I.D.a., Medicinal Benefits Of Anise Seeds (Pimpinella Anisum) And Thymus Vulgaris In A Sample Of Healthy Volunteers. Int. J. Res. Ayurveda Pharm., 2017. 8(3): p. 6. https://doi.org/10.7897/22774343.083150

78. Foroughi, A., et al., Evaluation of antibacterial activity and phytochemical screening of Pimpinella anisem's essential oil. International Journal of Pharmacognosy and Phytochemical Research, 2016. 8(11): p. 18861890.

79. G In [n, ., et al., Screening of antioxidant and antimicrobial activities of anise (Pimpinella anisum L.) seed extracts. Food chemistry, 2003. 83(3): p. 371-382. https://doi.org/10.1016/S0308-8146(03)00098-0

80. Rajeshwari, C., M. Abirami, and B. Andallu, In vitro and in vivo antioxidant potential of aniseeds (Pimpinella anisum). Asian Journal of Experimental Biological Sciences, 2011. 2(1): p. 80-89.

81. Tas, A., et al., Evaluation of analgesic and anti inflammatory activity of Pimpinella anisum fixed oil extract. Indian Veterinary Journal, 2006. 83(8): p. 840843.

82. Heidari, M. and M. Ayeli, Effects of methyl alcoholic extract of Pimpinella anisum L. on picrotoxin induced seizure in mice and its probable mechanism. 2005.

83. Jamshidzadeh, A., et al., An in vivo and in vitro investigation on hepatoprotective effects of Pimpinella anisum seed essential oil and extracts against carbon tetrachloride-induced toxicity. Iranian journal of basic medical sciences, 2015. 18(2): p. 205.

84. Rai, N., et al., Quality specifications on Piper nigrum L. A spice and herbal drug of Indian commerce. International Journal of Advanced Food Science and Technology, 2012. 1(1): p. 1-11.

85. Abdallah, E. and W. Abdalla, Black pepper fruit (Piper nigrum L.) as antibacterial agent: A mini-review. J Bacteriol Mycol Open Access, 2018. 6(2): p. 141-145. https://doi.org/10.15406/jbmoa.2018.06.00192

86. Zuzanna Bober, Z., et al., Medicinal benefits from the use of Black pepper, Curcuma and Ginger. European Journal of Clinical and Experimental Medicine, 2018(2): p. 133-145. https://doi.org/10.15584/ejcem.2018.2.9 
87. Liu Q, M.X., Li Y, , Antibacterial and Antifungal Activities of Spices. Int J Mol Sci., 2017. 18(6). https://doi. org/10.3390/ijms18061283

88. Abdallah*, E.M., Black Seed (Nigella sativa) As Antimicrobial Drug: A Mini-Review. Novel Approaches in Drug Designing \& Development, 2017. 3(2).

89. Yadav, R., R. Kaushik, and D. Gupta, The health benefits of Trigonella foenum-graecum: A review. Int J Eng Res Appl, 2011. 1(1): p. 32-35.

90. Branch, S., Fenugreek (Trigonella foenum-graecum L.) as a valuable medicinal plant. International Journal of
Advanced Biological and Biomedical Research, 2013. 1(8): p. 922-931.

91. Hajimehdipoor, H., et al., Identification and Quantitative Determination of 4-Hydroxyisoleucine in Trigonella foenum-graecum L. from Iran. Journal of Medicinal Plants ; 2010. 1(33): p. 29-34.

92. Snehlata, H.S. and D.R. Payal, Fenugreek (Trigonella foenum-graecum L.): an overview. Int J Curr Pharm Rev Res, 2012. 2(4): p. 169-87.

93. Mahbub, J., et al., biological and medicinal significance of Trigonella foenum-graecum: A. 2015. 